\title{
Metastatic urothelial carcinoma to pericardia manifested by dyspnea from cardiac tamponade during systemic chemotherapy: Case report and literature review
}

\author{
Seiya Hattori, MD; Akira Miyajima, MD, PhD; Takahiro Maeda, MD; Toshikazu Takeda, MD; Shinya Morita, \\ MD; Takeo Kosaka, MD; Eiji Kikuchi, MD, PhD; Mototsugu Oya, MD, PhD
}

Department of Urology, Keio University School of Medicine, Tokyo, Japan

Cite as: Can Urol Assoc J 2012;6(5):E184-E188. hitp://dx.doi.org/10.5489/cuaj.11130

\section{Abstract}

A 53-year-old man presented for further evaluation due to microscopic hematuria and left lumbar pain. Computed tomography revealed a large tumour in the left renal pelvis with multiple metastases. Despite effective systemic chemotherapy, he developed dyspnea, and was diagnosed with cardiac tamponade. Pericardial involvement in an advanced malignancy is common, but symptomatic cardiac metastasis from urothelial carcinoma is rare. Of the reports of symptomatic cardiac metastasis from urothelial carcinoma, only 3 cases presented as cardiac tamponade. We report here a rare case of cardiac tamponade caused by a renal pelvic carcinoma with positive cytodiagnosis of pericardial effusion. We also summarize and discuss the symptoms, treatment, and prognosis of the pathological condition, and present a brief review of previously published reports.

\section{Introduction}

The incidence of cardiac metastasis has been reported to be $2.3 \%$ and $18.3 \%$ of autopsied cases of carcinoma. ${ }^{1,2}$ It has been reported that $10 \%$ of autopsied cases of urothelial carcinoma (UC) exhibited cardiac metastases. ${ }^{3}$ However, the metastases are clinically silent in most cases. To the best of our knowledge, there have only been a few reports of symptomatic cardiac metastasis from UC, and only 3 cases presented as cardiac tamponade. We report a rare case of cardiac tamponade caused by UC of the renal pelvis, and discuss the symptoms, treatment, and prognosis of the pathological condition. We also briefly review published reports.

\section{Case report}

In June 2006, a 53-year-old man visited our department for further evaluation of microscopic hematuria and left lumbar pain. Abdominal computed tomography (CT) revealed the presence of a tumour in the left renal pelvis with left reniportal lymph node metastases, multiple lung metastases, multiple liver metastases and left pubic bone metastasis. A retrograde pyelogram revealed a filling defect in the left renal pelvis, and urine cytology collected from the left renal pelvis was morphologically similar to UC (class V). After the patient received 4 cycles of MVAC chemotherapy (methotrexate, vinblastine, adriamycin, and cisplatin), radiological findings demonstrated that MVAC therapy was not effective. He underwent 6 additional cycles of chemotherapy combined with gemcitabine and paclitaxel. The left reniportal lymph node metastases, lung metastases and liver metastases decreased in size. After the sixth cycle of gemcitabinepaclitaxel chemotherapy, the patient gradually developed chest discomfort and dyspnea. X-rays showed an enlarged cardiac silhouette and left pleural effusion. CT revealed massive pericardial effusion and left pleural effusion, which were not detected in a CT scan performed a month earlier (Fig. 1). Pericardiocentesis was performed, and $3000 \mathrm{~mL}$ of pericardial effusion and $100 \mathrm{~mL}$ of left pleural effusion were aspirated. Both of the samples were clear yellow, and cytodiagnosis of both fluids demonstrated atypical cells similar to the cells present in urine from the left renal pelvis (class V) (Fig. 2). Subsequent CT showed an $8 \times 7 \times 6 \mathrm{~cm}$ pericardial mass invading the left posterior ventricular wall. Echocardiography showed a 5-cm pericardial mass adhering to the left lateral and posterior ventricular wall, resulting in severe akinesis of the cardiac wall (Fig. 3). Pericardiac effusion did not increase after the puncture, but a subsequent echocardiogram revealed the left ventricular akinetic lesion had expanded, leading to worsening of the cardiac function. He died of severe heart failure a month later.

\section{Discussion}

According to a recent review, the incidence of cardiac metastasis ranges from $2.3 \%$ to $18.3 \%$ of autopsied cases of carcinoma. ${ }^{1}$ In a large series of 7289 autopsy examinations, the incidence of cardiac metastases diagnosed post-mortem was $9.1 \%$, and tumours showing the highest rate were pleu- 


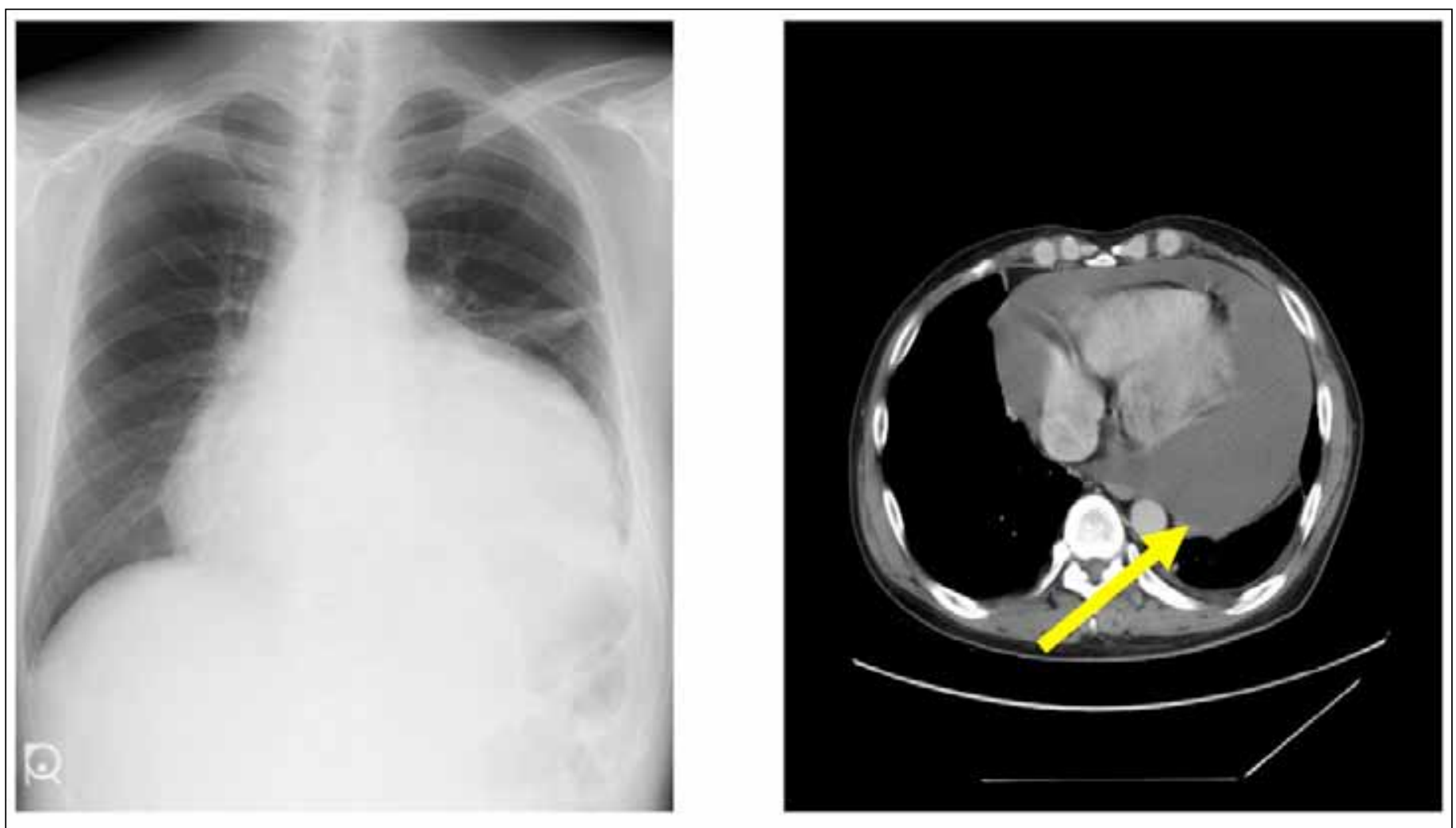

Fig. 1. X-ray and computed tomography showing massive pericardial effusion and left pleural effusion.

ral mesothelioma (48.4\%), melanoma $(27.8 \%)$, lung adenocarcinoma $(21 \%)$, undifferentiated carcinomas (19.5\%), lung squamous cell carcinoma $(18.2 \%)$ and breast carcinoma $(15.5 \%){ }^{2}$ In the case of UC, $10 \%$ of autopsied cases show cardiac metastases. ${ }^{4}$ Pericardial effusions were found in $25.4 \%$ of those with cardiac involvement. However, cases presented as clinically significant cardiac tamponade are rare. Including the present case, 14 cases of symptomatic cardiac metastases from UC have been reported so far: 7 bladder cancers and 7 renal pelvic cancers. ${ }^{4-16}$ (Table- 1 ). There have been 3 reported cases of cardiac tamponade from urothelial carcinoma. ${ }^{4,5,7}$ In all the cases, symptoms included dyspnea, fatigue, orthopnea and chest pain. Plain chest radiography revealed an enlarged cardiac silhouette or "water bottle" heart. Echocardiography was useful to evaluate pericardial effusions in both cases. Differentiation of the etiology of effusions was performed via pericardiocentesis, which also provides safe and rapid relief of the low-output symptoms of cardiac tamponade. Although bloody pericardial effusion suggests malignancy in $75 \%$ of cases, ${ }^{3}$ the cytodiagnosis of pericardial effusion was negative in the former 2 cases. In the other case, the cytodiagnosis suggested malignancy. ${ }^{4,5,7}$

In our case, symptoms were similar to previously reported cases. Plain chest radiography showed a "water bottle" heart, and echocardiography was useful to evaluate pericar- dial effusion. Pericardiocentesis relieved the patient from the symptoms of cardiac tamponade. Although the pericardial effusion was clear, the cytodiagnosis was positive.

Treatment options for malignant pericardial effusions include pericardiocentesis, pericardial window and systemic chemotherapy. ${ }^{4}$ Pericardiocentesis does not improve survival and has a high recurrence rate, ${ }^{17}$ but it is useful for relieving patients from the low-output symptoms of cardiac tamponade. Surgical pericardial windows or possibly balloon pericardiotomy should be used for recurrences. ${ }^{17}$ In the present case, pericardiocentesis was effective, but persisting reno-cardiac failure prevented us from performing additional systemic chemotherapy.

An echocardiogram was useful for diagnosis in almost every case previously reported. On the other hand, X-rays and CT were useful for diagnosis in more than half of the cases, but could not exclude the presence of cardiac disease (Table 1). In our case, X-rays, CT and echocardiograms were positive studies and useful for diagnosis.

The prognosis of patients with symptomatic cardiac metastases from $U C$ is extremely poor. Although UC might respond to systemic chemotherapy, this does not appear to be practical because symptomatic cardiac metastases do not allow adequate time for cure.

In 2 cases, the patient received chemotherapy and survived for 6 months and 1 year, respectively., ${ }^{4,7}$ In 3 cases, 

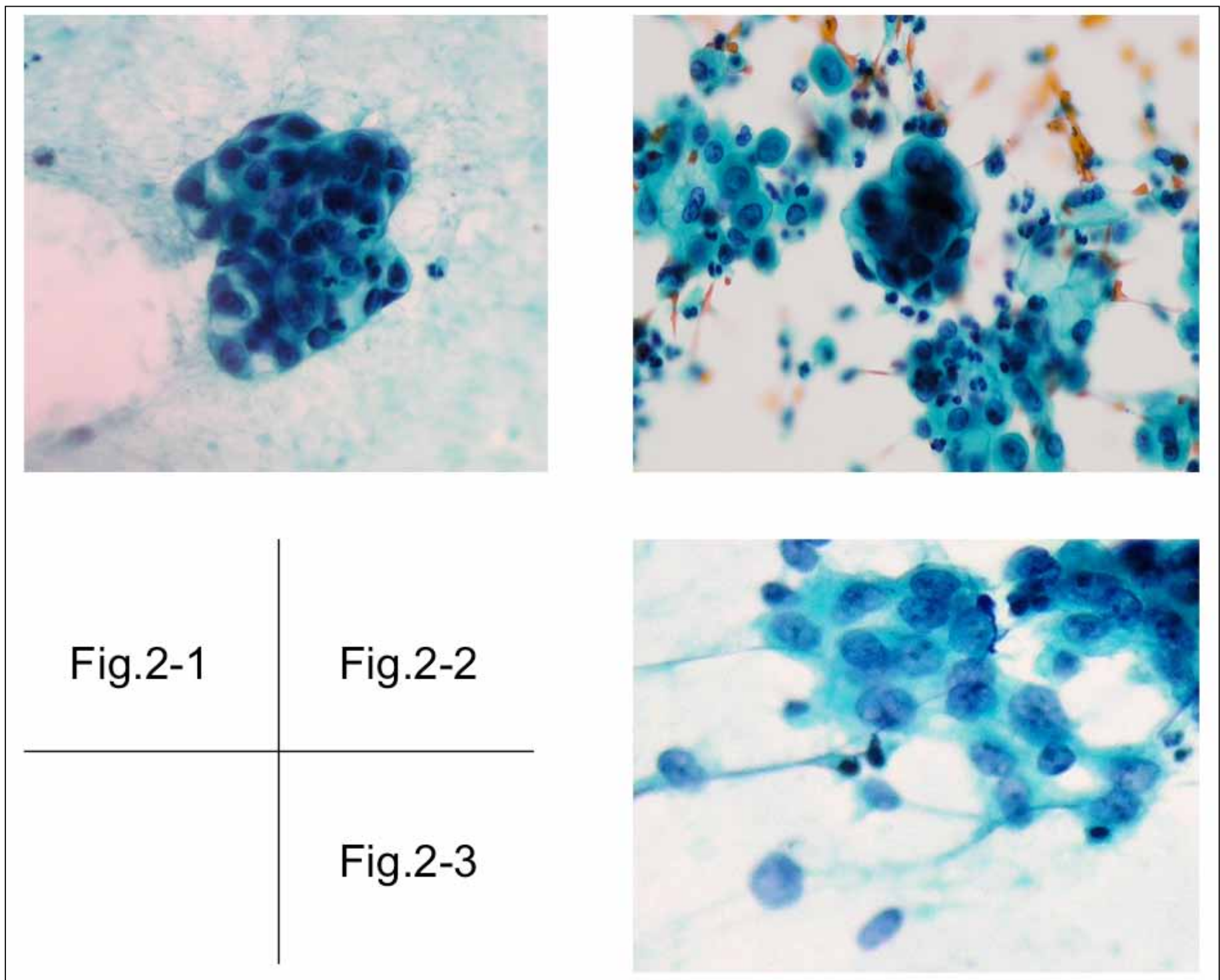

Fig. 2. Both pericardial effusion and left pleural effusion were clear yellow, and cytodiagnosis from both fluids demonstrated atypical cells similar to the cells present in urine from the left renal pelvis. 2-1: Cytodiagnosis of the pericardial effusion; 2-2: Cytodiagnosis of the left pleural effusion; 2-3: Cytodiagnosis of urine from the left renal pelvis.

the tumour in the heart was removed, ${ }^{6,13,16}$ but the operation was effective in only 1 case. ${ }^{16}$ However, in the other cases, the patients died soon after the operation. We, therefore, suggest that although the prognosis of symptomatic cardiac metastasis of UC is extremely poor, early diagnosis and treatment can help in the management of this life-threatening pathological condition, and an echocardiogram can be useful for early detection.

\section{Conclusion}

The present case is a rare case of cardiac tamponade from renal pelvic carcinoma with positive cytodiagnosis of pericardial effusion. The prognosis of symptomatic cardiac metastasis from a UC is extremely poor. Therefore, the treatment methods must be chosen carefully, and pericardiocentesis, which provides safe and rapid relief of the low-output symptoms of cardiac tamponade, can be an appropriate treatment option. Also, cytodiagnosis of pericardial effusion may help in the diagnosis, regardless of the appearance of the effusion.

Competing interests: None declared.

This paper has been peer-reviewed. 


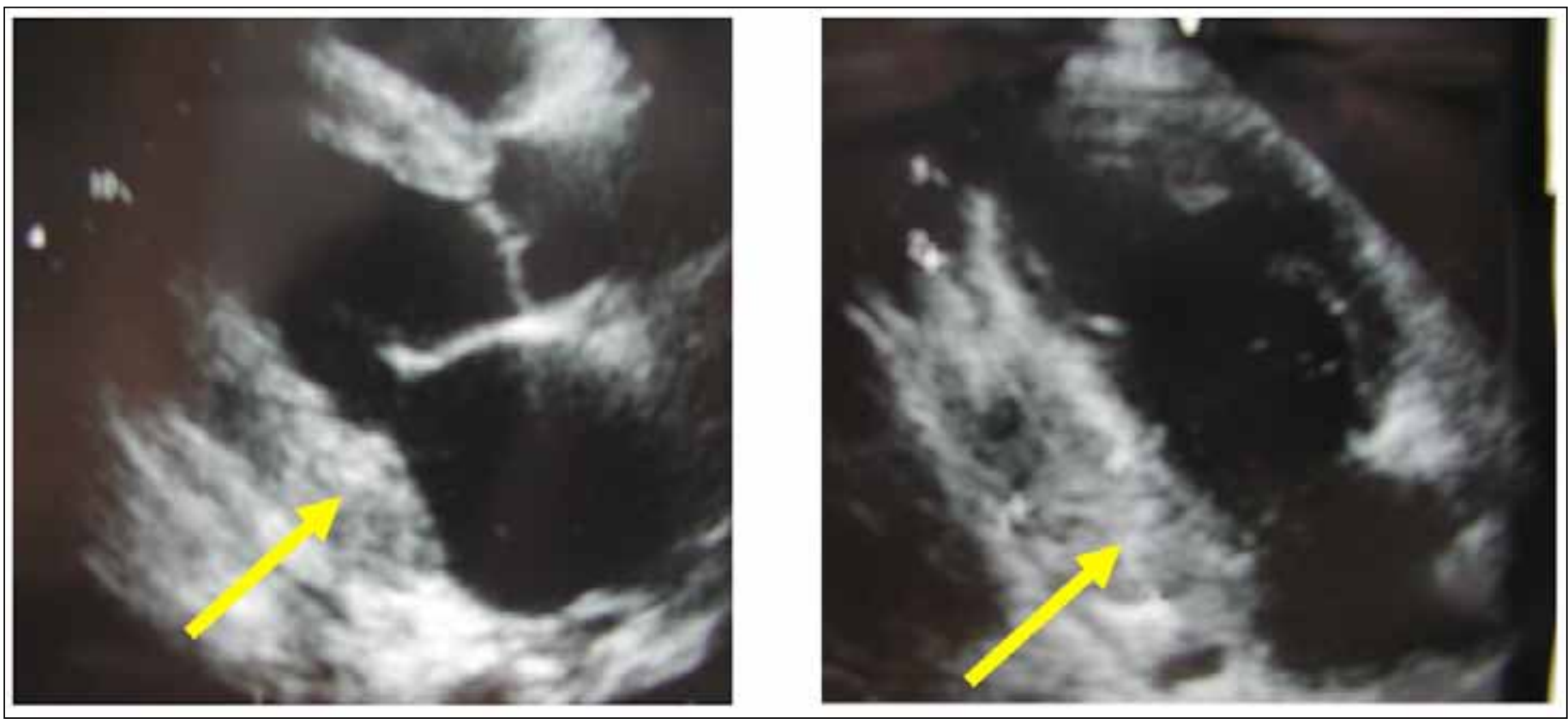

Fig. 3. Echocardiography showed a $5-\mathrm{cm}$ pericardial mass adhering to the left lateral and posterior ventricular wall

\begin{tabular}{|c|c|c|c|c|c|c|c|c|}
\hline Reporter & Age/sex & $\begin{array}{l}\text { Metastatic } \\
\text { lesion }\end{array}$ & $\begin{array}{l}\text { Primary } \\
\text { lesion }\end{array}$ & Tamponade & Cytology & Diagnosis & Treatment & Prognosis \\
\hline Fabozzi $^{4}$ & $66 \mathrm{M}$ & Pericardium & Bladder & $\begin{array}{l}\text { Bloody } \\
700 \mathrm{cc}\end{array}$ & $\begin{array}{l}\text { Anaplastic } \\
\text { cells }\end{array}$ & $X P$, echo & $\begin{array}{c}\text { Pericardial } \\
\text { window } \\
\text { Chemotherapy }\end{array}$ & $\begin{array}{c}\text { DOD } \\
\text { (6 months) }\end{array}$ \\
\hline Islam $^{5}$ & $39 M$ & $\begin{array}{c}\text { Left } \\
\text { ventricular }\end{array}$ & $\begin{array}{l}\text { Renal } \\
\text { pelvis }\end{array}$ & $\begin{array}{l}\text { Bloody } \\
200 \mathrm{cc}\end{array}$ & Negative & $\mathrm{XP}$, echo & Pericardiocentesis & Not described \\
\hline Spiliotopoulos ${ }^{7}$ & $66 \mathrm{M}$ & Right atrial & Bladder & $\begin{array}{l}\text { Bloody } \\
2000 \mathrm{ml}\end{array}$ & $\begin{array}{c}\text { s/o } \\
\text { malignancy }\end{array}$ & Echo/CT MRI & Chemotherapy & $\begin{array}{c}\text { Alive One } \\
\text { year }\end{array}$ \\
\hline Kemp ${ }^{6}$ & $53 \mathrm{M}$ & $\begin{array}{c}\text { Right } \\
\text { ventricular }\end{array}$ & Bladder & $x$ & - & Echo & Sternotomy & $\begin{array}{c}\text { DOD } \\
\text { (shortly after) }\end{array}$ \\
\hline Patel $^{8}$ & $45 \mathrm{M}$ & $\begin{array}{c}\text { Right } \\
\text { ventricular }\end{array}$ & $\begin{array}{l}\text { Renal } \\
\text { pelvis }\end{array}$ & $x$ & - & CT Echo $(3 \mathrm{~cm})$ & Supportive care & $\begin{array}{c}\text { DOD } \\
\text { (shortly after) }\end{array}$ \\
\hline $\operatorname{Lin}^{9}$ & $83 \mathrm{M}$ & $\begin{array}{c}\text { Right } \\
\text { ventricular }\end{array}$ & Bladder & $x$ & - & $\begin{array}{c}\text { Echo CT }(5 \times 4 \\
\mathrm{cm})\end{array}$ & Denied treatment & $\begin{array}{c}\text { DOD } \\
\text { (shortly after) }\end{array}$ \\
\hline Murakami ${ }^{10}$ & $66 \mathrm{M}$ & $\begin{array}{c}\text { Right } \\
\text { ventricular }\end{array}$ & $\begin{array}{l}\text { Renal } \\
\text { pelvis }\end{array}$ & $x$ & - & $\begin{array}{c}\text { Echo }(0.8 \mathrm{~cm}) \\
\text { CT }\end{array}$ & None & $\begin{array}{c}\text { DOD } \\
\text { (shortly after) }\end{array}$ \\
\hline Kadono ${ }^{11}$ & $57 \mathrm{M}$ & $\begin{array}{c}\text { Right } \\
\text { ventricular }\end{array}$ & $\begin{array}{l}\text { Renal } \\
\text { pelvis }\end{array}$ & $x$ & - & Echo & None & $\begin{array}{c}\text { DOD } \\
\text { (shortly after) }\end{array}$ \\
\hline Clemente $^{12}$ & $53 \mathrm{M}$ & $\begin{array}{c}\text { Right } \\
\text { ventricular }\end{array}$ & Bladder & $x$ & - & Echo & None & $\begin{array}{c}\text { DOD } \\
\text { (shortly after) }\end{array}$ \\
\hline Sobczyk $^{13}$ & $75 \mathrm{M}$ & $\begin{array}{c}\text { Left } \\
\text { ventricular }\end{array}$ & $\begin{array}{l}\text { Renal } \\
\text { pelvis }\end{array}$ & $x$ & - & Echo $(4.5 \mathrm{~cm})$ & Operation & $\begin{array}{c}\text { DOD } \\
\text { (one month) }\end{array}$ \\
\hline Malde $^{14}$ & $77 \mathrm{~F}$ & $\begin{array}{c}\text { Left } \\
\text { ventricular }\end{array}$ & Bladder & $x$ & - & - & None & $\begin{array}{c}\text { DOD } \\
\text { (shortly after) }\end{array}$ \\
\hline Mountzious ${ }^{15}$ & $67 \mathrm{M}$ & Right atrial & Bladder & $\begin{array}{c}\text { Not } \\
\text { mentioned }\end{array}$ & $\begin{array}{l}\text { Epithelial } \\
\text { cells }\end{array}$ & $\begin{array}{l}\text { Echo/CT MRI } \\
\quad(4.6 \mathrm{~cm})\end{array}$ & Chemotherapy & $\begin{array}{c}\text { DOD } \\
\text { (one year) }\end{array}$ \\
\hline Shields ${ }^{16}$ & $58 \mathrm{~F}$ & $\begin{array}{c}\text { Right } \\
\text { Ventricular }\end{array}$ & $\begin{array}{l}\text { Renal } \\
\text { pelvis }\end{array}$ & $x$ & - & Echo/CT MRI & $\begin{array}{c}\text { Operation } \\
\text { Adjuvant chemo }\end{array}$ & $\begin{array}{l}\text { Alive Nine } \\
\text { weeks }\end{array}$ \\
\hline Our case & $53 \mathrm{M}$ & $\begin{array}{c}\text { Left } \\
\text { ventricular }\end{array}$ & $\begin{array}{l}\text { Renal } \\
\text { pelvis }\end{array}$ & $\begin{array}{l}\text { Clear, } \\
3000 \text { cc }\end{array}$ & Class v & $\begin{array}{c}\text { Echo }(8 \mathrm{~cm}) \mathrm{CT} \\
(5 \mathrm{~cm}) \mathrm{XP}\end{array}$ & Pericardiocentesis & $\begin{array}{c}\text { DOD } \\
\text { (one month) }\end{array}$ \\
\hline
\end{tabular}

M: male; F: female; DOD: dead of disease; XP: x-ray photographs; CT: computed tomography; MRI: magnetic resonance imaging 
Hattori et al.

\section{References}

1. Gupta R, Paner GP, Amin MB. Neoplasms of the upper urinary tract: a review with focus on urothelial carcinoma of the pelvicalyceal system and aspects related to its diagnosis and reporting. Adv Anat Pathol 2008;15:127-39. http://dx.doi.org/10.1097/PAP.0b013e31817145a9

2. Bussani R, De-Giorgio F, Abbate A, et al. Cardiac metastases. J Clin Pathol 2007;60:27-34. http:// dx.doi.org/10.1136/icp.2005.035105

3. Klatt EC, Heitz DR. Cardiac metastases. Cancer 1990;65:1456-9. http://dx.doi.org/10.1002/10970142(19900315)65:6<1456::AID-CNCR2820650634>3.0.C0;2-5

4. Fabozzi SJ, Newton JR Jr, Moriarty RP, et al. Malignant pericardial effusion as initial solitary site of metastasis from transitional cell carcinoma of the bladder. Urology 1995;45:320-2. http://dx.doi. org/10.1016/0090-4295(95)80025-5

5. Islam N, Ahmedani MY. Renal carcinoma presenting as cardiac tamponade: a case report and review of literature. Int J Cardiol 1998;64:207-11. http://dx.doi.org/10.1016/S0167-5273(98)00015-1

6. Kemp W, Rothberg M, Saporito JJ, et al. Transitional cell carcinoma and right ventricular obstruction. J Urol 1997;158:1522-3. http://dx.doi.org/10.1016/S0022-5347(01)64260-5

7. Spiliotopoulos K, Argiriou M, Argyrakos T, et al. Solitary metastasis of urothelial carcinoma of the urinary bladder to the heart: an unusual clinical manifestation. J Thorac Cardiovasc Surg 2008;136:1377-8.

8. Patel AK, Moorthy AV, Yap VU, et al. Cardiac metastasis from transitional cell carcinoma: a subtle echocardiographic entity. J Clin Ultrasound 1980;8:49-51. http://dx.doi.org/10.1002/icu.1870080111

9. Lin WC, Telen MJ. Cardiac metastasis from a transitional cell carcinoma: a case report. Med Oncol 2000;17:147-50. http://dx.doi.org/10.1007/BF02796211

10. Murakami T, Komiya A, Mikata K, et al. Cardiac metastasis of renal pelvic cancer. Int J Urol 2007; 14:2401. http://dx.doi.org/10.1111/j.1442-2042.2007.01512.x
11. Kadono Y, Yamamoto H, Tajika E. Cardiac metastasis from a transitional cell carcinoma diagnosed by two-dimensional echocardiography. Int J Urol 2006;13:454-6. http://dx.doi.org/10.1111/j.14422042.2006.01323.x

12. Clemente LM, Patier JL, Lopez-Suanzes MJ, et al. Cardiac metastases from a transitional cell carcinoma: an unusual clinical manifestation. Br J Urol 1997;80:831-2. http://dx.doi.org/10.1046/i.1464410X.1997.00394.X

13. Sobczyk D, Nosal M, Myc J, et al. Cardiac metastasis due to pulmonary metastasis from a transitional cell carcinoma. Eur J Echocardiogr 2008;9:113-5.

14. Malde DJ, Gall Z, George N. Ventricular rupture secondary to cardiac metastasis of transitional cell carcinoma of the bladder. Scand J Urol Nephrol 2006;40:170-1. http://dx.doi.org/10.1080/00365590510040372

15. Mountzios G, Bamias A, Dalianis A, et al. Endocardial metastases as the only site of relapse in a patient with bladder carcinoma: a case report and review of the literature. Int J Cardiol 2010; 140:e4-7. http:// dx.doi.org/10.1016/i.i.jcard.2008.11.012

16. Shields AM, Pomplun S, Deshpande R, et al. Right ventricular metastasis of transitional cell carcinoma of the renal pelvis: successful single stage surgical treatment. Interact Cardiovasc Thorac Surg 2011;12:297300. http://dx.doi.org/10.1510/icvts.2010.256230

17. Vaitkus PT, Herrmann HC, LeWinter MM. Treatment of malignant pericardial effusion. JAMA 1994;272:5964. http://dx.doi.org/10.1001/jama.1994.03520010071035

Correspondence: Dr. Akira Miyaijma, Department of Urology, Keio University School of Medicine, 35 Shinanomachi, Shinjuku-ku, Tokyo 160-8582, Japan; akiram@a8.keio.jp 